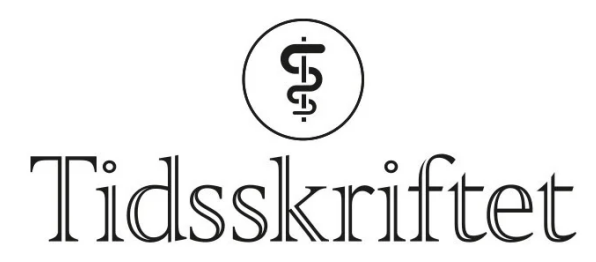

DEN NORSKE LEGEFORENING

\title{
AD/HD hos barn etter feberkramper
}

\author{
FRA ANDRE TIDSSKRIFTER
}

BETTY KALIKSTAD

Institutt for klinisk medisin

Universitetet i Oslo

\section{Gjentatte episoder med feberkramper hos barn er assosiert med økt risiko for utvikling av AD/HD.}

$\mathrm{AD} / \mathrm{HD}$ (attention deficit/hyperactivity disorder) er en heterogen nevrobiologisk tilstand som gir vansker knyttet til sosiale, emosjonelle og atferdsmessige forhold, med konsekvenser for læring og kognitiv utvikling. Faktorer som kan ha betydning for sammenhengen mellom feberkramper og AD/HD er undersøkt i en studie som nylig er publisert i Archives of Disease in Childhood (1). Studien fra Taiwan inkluderte over tusen barn $\mathrm{i}$ alderen $6 \mathrm{md} .-5$ år med diagnosen feberkramper. Dataene ble hentet fra en nasjonal database for perioden 2000-10. Barn med diagnosene AD/HD og hyperkinetisk syndom, epilepsi og kramper, myoklonier eller kramper (hos nyfødte) ble ekskludert.

Studiekohorten ble sammenliknet med en kontrollgruppe ut fra alder, kjønn, urbaniseringsnivå og foreldrenes yrke.

Barn med gjentatte feberkramper hadde signifikant høyere risiko for utvikling av AD/HD i løpet av studieperioden enn kontrollgruppen (OR 1,66, 95 \% KI 1,27-2,18). Risikoen økte med hyppigheten av registrerte feberkramper. Høy urbaniseringstetthet var også knyttet til høy forekomst av AD/HD.

- Matchet pasienet-kontroll-design er en god måte å kontrollere for kofunderende faktorer på, sier lege og postdoktorstipendiat Pål Surén ved Folkehelseinstituttet.

- Hovedfunnet, dvs. at barn med feberkramper har større risiko for senere å få en AD/HDdiagnose er solid, men forfatterne legger kanskje for mye vekt på forskjeller mellom undergruppene. Det er relativt få barn med AD/HD-diagnoser i hver undergruppe, og siden konfidensintervallene er overlappende, bør man være forsiktig i fortolkningen av forskjeller mellom dem, sier han.

- Taiwan har et avansert helsevesen og gode levekår, så studien har overføringsverdi til norske forhold. Slike studier vil også kunne gjøres i Norge, ettersom tilsvarende data finnes i den norske mor-og-barn-undersøkelsen og i Norsk pasientregister, sier Surén. 
1. Ku YC, Muo CH, Ku CS et al. Risk of subsequent attention deficit-hyperactivity disorder in children with febrile seizures. Arch Dis Child 2014; 99:322-6. [PubMed] [CrossRef]

Publisert: 2. september 2014. Tidsskr Nor Legeforen. DOI: 10.4045/tidsskr.14.0951

(C) Tidsskrift for Den norske legeforening 2023. Lastet ned fra tidsskriftet.no 26. april 2023. 